\title{
PENGEMBANGAN MEDIA PEMBELAJARAN BERBASIS FLASH MX PADA MATA PELAJARAN MUHADATSAH
}

\author{
Farida Nur Jannah, M. Dzikrul Hakim Al Ghozali \\ Universitas KH. A. Wahab Hasbullah Jombang \\ email: nurjannahfar03@gmail.com
}

\begin{abstract}
The research using the ADDIE went through these phases: (1) Analysis Phase was problem analysis, material analysis, learners character analysis, learning purpose, and learners need. (2) The design phase was making the media in Microsoft PowerPoint and steps of producing media in Flash MX. (3) Development Phase was validating the product to material expert and media expert. (4) The implementation phase was practicing for the class tent of MA AlI'dadiyyah Bahrul Ulum learners with 22 learners to do effectiveness test, which is pre and post-test after Macromedia Flash MX based learning media was given. (5) Evaluation Phase was to see the effective and evaluation was extracted from learners response. The validated media according to assessment from material expert validation (Arab Language Department's Lecturer) was 4,1 with very valid category, evaluation from the material expert (muhadatsah course teacher) was 4,6 with very accurate class, whereas media expert was 3,7 with correct category and learners response as much as $87 \%$ with very agree to category. Effectiveness test was from normality test, homogeneity test, and simple paired t-test concluded that $\mathrm{Ha}$ accepted than Ho rejected means Macromedia Flash MX used media development was effective in muhadatsah learning in the tenth class of MA Al-I'dadiyyah.
\end{abstract}

Keywords: Media Development; Flash MX; Muhadatsah Learning.

\begin{abstract}
Abstrak
Penelitian ini menggunakan model ADDIE yang melalui tahap sebagai berikut: (1) Tahap Analisis dilakukan analisis masalah, analisis materi, analisis karakteristik peserta didik, tujuan pembelajaran dan kebutuhan peserta didik. (2) Tahap Desain dilakukan dengan pembuatan di Microsoft PowerPoint dan tahap-tahap pembuatan Flash MX. (3) Tahap Pengembangan dilakukan dengan validasi produk media kepada para ahli materi dan ahli media. (4) Tahap Implementasi dilakukan pada peserta didik kelas X MA Al-I'dadiyyah Bahrul Ulum dengan jumlah peserta didik 22 siswa untuk melakukan uji keefektifan
\end{abstract}


yang berupa pre test dan post test setelah diberikan media pembelajaran berbasis Flash MX. (5) Tahap Evaluasi dilakukan untuk melihat keefektifan media dan evaluasi diperoleh dari hasil respon peserta didik. Kevalidan media berdasarkan penilaian dari validasi ahli materi (Dosen Pendidikan Bahasa Arab) terdapat 4,1 dengan kategori sangat valid, penilaian dari validasi ahli materi (guru mata pelajaran muhadatsah) terdapat 4,6 dengan kategori sangat valid, sedangkan ahli media terdapat 3,7 dengan kategori valid dan respon peserta didik terdapat 87\% dengan kategori sangat setuju. Uji keefektifan bahwa hasil dari uji normalitas, uji homogenitas dan simple paired t test disimpulkan bahwa Ha diterima maka Ho ditolak artinya Pengembangan media berbasis Flash MX Efektif digunakan dalam pembelajaran muhadatsah Pada kelas X MA Al-I'dadiyyah.

Kata Kunci: Pengembangan Media; Flash MX; Pembelajaran Muhadatsah.

\section{A. Pendahuluan}

Dalam kegiatan pembelajaran, ada dua elemen yang sangat penting, yaitu metode untuk mengajar dan media dalam pembelajaran. Kedua aspek ini saling berkaitan. Pilihan suatu metode pendidikan tertentu akan mempengaruhi jenis metode pengajaran yang sesuai, meskipun selain itu masih ada banyak aspek lain yang harus dipertimbangkan ketika memilih sarana, termasuk tujuan pembelajaran, jenis tugas, dan respons yang diharapkan oleh siswa.

Media pembelajaran juga memiliki fungsi yang penting dalam pembelajaran, salah satu fungsi utamanya adalah sebagai alat pendidikan yang dapat membantu guru dalam menyampaikan materi.. penggunaan media pembelajaran dalam proses belajar mengajar dapat meningkatkan semangat dan antusiasme siswa. Media juga dapat digunakan untuk mengajar ilmu bahasa di samping ilmu-ilmu yang lain untuk mencapai tujuan yang optimal.

Bahasa adalah suara di mana setiap orang mengekspresikan perasaan dan ide-ide mereka, dan itu adalah karakteristik di mana seseorang telah dikenal, dan tanpa lidah yang mengungkapkan, kebutuhannya maka tidak dapat diketahui oleh manusia lain. Dia tidak dapat mengevaluasi apa yang dia katakan sebagai bukti lengkap dari perkenalan yang benar, dan seperti halnya sains yang dapat membuktikan kepada hewan yaitu non-manusia menggunakan bahasa komunikasi.

Dapat dikatakan bahwa bahasa adalah sarana atau alat di mana seseorang mengekspresikan perasaan dan pikiran, juga sebagai sarana komunikasi. Bahasa adalah bahasa yang indah dan Allah Yang Maha Kuasa menghormatinya dengan wahyu Al-Qur'an yang Mulia. Ada empat keterampilan dalam memahami bahasa Arab yaitu mendengar, membaca, berbicara, dan menulis. Dan dalam keterampilan berbicara, mengajarkan muhadatsah, seseorang tidak bisa berbicara secara berdialog tanpa ada 
media. Dalam keterampilan berbicara, ada banyak ajaran di mana seseorang melakukan percakapan.

Perlu menjelaskan pentingnya muhadatsah dalam belajar bahasa, karena pengetahuan tentang bahasa apa pun akan terlihat terutama pada tingkat komunikasi lisan, sehingga dalam karakteristiknya, mendefinisikan bahasa dengan mengatakan: mereka adalah suara di mana semua orang mengekspresikan tujuan mereka. Rushdi Tuaima mencatat, menekankan bahwa tujuan pertama, tujuan pengajaran bahasa adalah untuk memberikan pelajar kemampuan untuk berkomunikasi dengan penutur bahasa target.

Mata pelajaran bahasa Arab merupakan mata pelajaran untuk mendorong, membimbing, mengembangkan, dan membina kemampuan dan sikap yang positif baik secara reseptif maupun produktif terhadap bahasa Arab. Tujuan pembelajaran bahasa Arab telah diatur berdasarkan peraturan Menteri Agama RI No. 000912 Th 2013 tentang Kurikulum Madrasah dalam Standar Isi bertujuan untuk pencapaian kompetensi dasar berbahasa yang antara lain menyimak, berbicara, membaca, dan menulis. ${ }^{1}$

Muhadatsah sudah diajarkan mulai sejak usia dini, baik belajar menggunakan bahasa sendiri atau bahasa asing termasuk bahasa Arab. Muhadatsah juga diajarkan pada siswa di tingkat Aliyah termasuk di Madrasah Aliyah Al-I'dadiyyah juga diajarkan muhadatsah pada kelas X.

Berdasarkan hasil dari pengamatan observasi di lapangan dan wawancara yang dilakukan dengan ibu Hanifatus Sholeha sebagai guru muhadatsah, ini menunjukkan bahwa pemahaman siswa tentang topik pada pembelajaran muhadatsah masih kurang atau rendah. Dengan penyampaian materi yang tidak menarik perhatian siswa menyebabkan siswa cenderung tidak fokus dan kurang semangat dalam mengikuti proses belajar mengajar dan sulit mengingat materi lagi terutama bahasa Arab. di samping itu, guru tidak mendapat manfaat dari fasilitas saat ini seperti layar LCD, sehingga sangat disayangkan jika tidak menggunakan fasilitas.

Permasalahan yang dihadapi siswa ini didasari pada kesulitan guru dalam menyediakan materi, dan akibatnya masih banyak siswa yang masih belum memenuhi nilai standar Kriteria Penyelesaian Minimum (KKM) untuk bidang studi dalam bahasa Arab dan terutama muhadatsah yang diterapkan. Dari informasi di atas, bahasa Arab dalam muhadatsah membutuhkan metode pendidikan yang dapat meningkatkan pemahaman siswa. Dalam proses pembelajaran, media pembelajaran sangat penting karena dapat membantu mengatasi ketidakjelasan materi yang diberikan oleh guru.

\footnotetext{
${ }^{1}$ Muhammad Jafar Shodiq, "Pembelajaran Bahasa Arab Aktif-Inovatif Berbasis Multiple Intelligences," Al Mahāra: Jurnal Pendidikan Bahasa Arab 4, no. 1 (2018): 125, https://doi.org/10.14421/almahara.2018-041-07.
} 
Metode pengajaran menggunakan media Aplikasi pada Flash $M X$ dapat membuat siswa lebih tertarik sehingga siswa lebih semangat, siswa lebih mudah dalam memahami materi yang disampaikan dan kemampuan untuk meningkatkan minat siswa. Mengingat situasi di atas, peneliti ingin mengembangkan media berbasis Flash $M X$ di sekolah menengah pertama. Melalui topik muhadatsah, siswa diharapkan untuk meningkatkan minat mereka dalam belajar.

Berdasarkan penjelasan pada latar belakang tersebut, maka fokus dari penelitian ini adalah: 1. Bagaimana mengembangkan media berbasis Flash MX dalam pembelajaran muhadatsah di sekolah Madrasah Aliyah AlI'dadiyyah Tambakberas Jombang? 2. Bagaimana keefektifan media pembelajaran berbasis Flash MX dalam pembelajaran muhadatsah pada kelas 10 Madrasah Aliyah Al-I'dadiyyah Tambakberas Jombang? Adapun tujuan penelitian ini adalah untuk menghasilkan media berbasis Flash MX untuk mata pelajaran muhadatsah pada kelas X Madrasah Aliyah AlI'dadiyyah Tambakberas Jombang.

\section{B. Metode Penelitian}

Peneliti menggunakan pendekatan penelitian dan pengembangan pada model ADDIE, dan peneliti lebih suka model ini karena langkah-langkah ini memiliki langkah prosedural yang sederhana dan jelas untuk mengembangkan alat bantu pengajaran, sehingga peneliti menjelaskan langkah-langkah berikut untuk membuat kurikulum lebih jelas. ${ }^{2}$

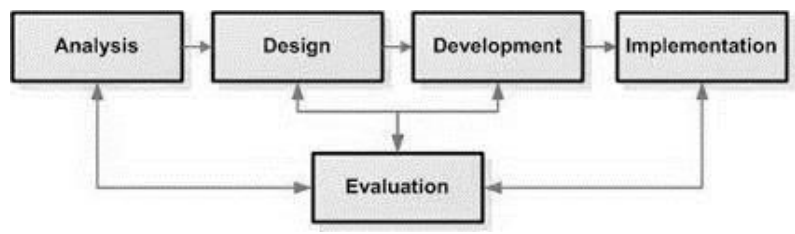

Analisis adalah tindakan pertama yang harus diambil oleh peneliti. Ini adalah analisis materi, analisis masalah, analisis karakteristik siswa dan kebutuhan siswa. Sedangkan design untuk mengidentifikasi masalah sesuai dengan analisis kebutuhan siswa, tujuan pengajaran, kompetensi dasar dan strategi pengajaran. Kemudian formulir bahan studi didasarkan pada hasil analisis kebutuhan siswa. Dalam tahapan pengembangan, peneliti mengembangkan media pembelajaran melalui komputer dan kemudian melakukan validasi kepada ahli materi dan ahli media untuk mengetahui kelayakan media. Dilanjutkan tahap implementasi, dimana desain dan

\footnotetext{
${ }^{2}$ Nunuk Suryani, Achmad Setiawan, dan Aditin Putria, Media Pembelajaran Inovatif dan Pengembangannya (Bandung: PT. Remaja Rosdakarya, 2018), h. 126.
} 
metode yang dikembangkan diterapkan di kelas dengan peserta didik yang berjumlah 22 siswa Dengan melakukan Uji keefektifan yang berupa pre-test dan post-test. Setelah media pembelajaran diterapkan pada peserta didik siswa diminta untuk mengisi angket respons peserta didik. Dan tahap akhir yaitu evaluasi yang dapat berlangsung di semua empat tahap yang disebutkan di atas, evaluasi dilakukan untuk melihat media pembelajaran berbasis Flash $M X$ efektif atau tidak efektif.

Instrumen pengumpulan data yang digunakan dalam penelitian ini adalah observasi, wawancara, kuesioner, respons siswa, dan tes. Data kuantitatif yang dibutuhkan oleh peneliti adalah dari pre-test, post-test dan kuesioner dari siswa, sedangkan data kualitatif yang dibutuhkan peneliti adalah dari observasi dan wawancara. Kemudian data dianalisis, yaitu 1 . analisis kevalidan dengan menganalisis hasil dari validasi ahli materi dan ahli media. 2. Analisis respons peserta didik, dengan menganalisis angket yang telah diisi oleh peserta didik setelah diberikan media pembelajaran. 3 . Uji keefektifan dengan menganalisis hasil dari pre-test dan post-test peserta didik dengan rumus uji Paired Sample t Test ${ }^{3}$ :

$$
\boldsymbol{t}=\frac{\overline{X_{1}}-\overline{X_{2}}}{\sqrt{\frac{s_{1}{ }^{2}}{n_{1}}+\frac{s_{2}{ }^{2}}{n_{2}}-2 r\left(\frac{s_{1}}{\sqrt{n_{1}}}\right)\left(\frac{s_{2}}{\sqrt{n_{2}}}\right)}}
$$

Keterangan:

$$
\begin{aligned}
& \overline{X_{1}}=\text { Rata-rata sampel } 1 \\
& \overline{X_{2}}=\text { Rata-rata sampel } 2
\end{aligned}
$$

$s_{1}=$ simpangan baku sampel 1

$s_{2}=$ simpangan baku sampel 2

$s_{1}{ }^{2}=$ varian sampel 1

$s_{2}{ }^{2}=$ varian sampel 2

$r=$ korelasi antara dua sampel

Setelah hasil sudah diketahui maka dapat disimpulkan sebagai berikut: Menurut Singgih Santoso, Pedoman pengambilan keputusan dalam uji Paired Sampel t -test berdasarkan nilai signifikansi (sig). Hasil output SPSS adalah sebagai berikut: Jika nilai Sig. (2-tailed) <0,05, maka Ho ditolak dan Ha diterima (efektif) dan Jika nilai Sig. (2-tailed) $>0,05$, maka Ho diterima dan Ha ditolak (tidak efektif).

${ }^{3}$ Singgih Santoso, Menguasai Statistik dengan SPSS 25 (Jakarta: PT Elex Media Komputindo, 2018), h. 94. 


\section{Hasil dan Pembahasan}

Bahasa Arab sebagai bahasa asing tetap menempati posisi penting di Indonesia, khususnya bagi umat Islam. Dalam mempelajari bahasa Arab, ada banyak keterampilan yang harus dipelajari, salah satunya adalah keterampilan berbicara dengan menambah kosakata dan berlatih berbicara menggunakan bahasa Arab. Pengetahuan kosakata sering dipandang penting dalam bahasa karena kosakata yang terbatas dapat menghambat komunikasi. Selanjutnya, selain menambah kosakata juga harus sering berlatih berbicara dalam bahasa Arab. ${ }^{4}$ Berlatih berbicara menggunakan bahasa Arab dapat dilakukan dengan muhadatsah.

Muhadatsah merupakan metode pembelajaran bahasa Arab yang seharusnya diajarkan pertama kali kepada para siswa atau kepada para pembelajaran karena tujuan utama belajar bahasa adalah mampu berdialog menggunakan bahasa sasaran yaitu bahasa Arab. Selanjutnya, muhadatsah yang diperoleh siswa dapat mengasah kemampuan dalam mengungkapkan kalimat untuk diungkapkan dalam bentuk ide, pendapat, rasa kepada lawan bicaranya.

Percakapan atau muhadatsah adalah cara seseorang untuk memenuhi kebutuhannya dan melaksanakan tuntutannya dalam masyarakat di mana ia tinggal, alat yang paling sering, dipraktekkan dan digunakan dalam kehidupan manusia dan lebih berharga dalam komunikasi sosial daripada menulis. ${ }^{5}$

Mahmoud Ali Al-Samman percaya bahwa tujuan pengajaran percakapan adalah: (1) Memberi siswa kata-kata, metode, makna dan ide, dan membiasakan mereka untuk mengatur dan menghubungkan ide-ide yang mereka miliki. (2) Siswa terbiasa dengan kemahiran dalam berbicara, kelancaran berbahasa, representasi makna, dan dapat membuat siswa lebih percaya diri. (3) Memperbaiki kesalahan psikologis siswa seperti introvert dan ketakutan. (4) Mengembangkan minat siswa dan memperkuat minat tersebut. $^{6}$

Adapun manfaat muhadatsah dalam kehidupan siswa adalah: (1) Siswa lebih berani mempraktekkan percakapan. (2)Siswa dapat memperbanyak mufrodat dan kalimat-kalimat bahasa Arab secara terus-menerus. (3) Selain melatih percakapan, siswa juga dapat melatih pendengaran sehingga mereka

\footnotetext{
${ }^{4}$ Muhammad Luqman Hakim, Asrowi Asrowi, dan Akhyar Akhyar, "Pengembangan Multimedia Interaktif Mata Pelajaran Bahasa Arab Materi Profesi Bagi Siswa Kelas VIII SMP IT Al-Huda Wonogiri," JTP - Jurnal Teknologi Pendidikan 20, no. 3 (2018): 249, http://journal.unj.ac.id/unj/index.php/jtp/article/view/9537.

${ }^{5}$ Mahmoud Ahmed El-Sayed, Dalam Cara Mengajar Bahasa Arab (Datsak: Preserved Publishing, 1997), h. 295.

${ }^{6}$ Muhammad Ali Al-Samman, Orientasi dalam Pengajaran Bahasa Arab (Mesir: Dar Al-Maarif, 1983), h. 245.
} 
dapat dengan fasih dan lancar dalam melafalkan bahasa Arab di mana pun. (4) Siswa dapat mengetahui maksud dan isi dari buku berbahasa Arab, berdialog menggunakan bahasa Arab, dan dapat berbicara menggunakan bahasa Arab. (5) Siswa akan lebih mudah menciptakan lingkungan berbahasa Arab di sekitarnya. (6) Siswa akan lebih menyukai pelajaran bahasa Arab dan lebih senang dengan bahasa Arab sebagai bahasa asingnya. (7) Siswa akan lebih mudah ketika membaca Al-Qur'an dan mudah membaca bukubuku yang berbahasa Arab. ${ }^{7}$

Pembelajaran muhadatsah dapat dilakukan dengan menggunakan media pembelajaran. Media pembelajaran memiliki peranan penting dalam menunjang kualitas belajar mengajar. Selain itu, media pembelajaran juga bergantung dengan kemampuan guru dalam menyajikan media dalam kegiatan pembelajaran. Media pembelajaran yang dikemas dengan baik akan memberikan peningkatan kemampuan siswa. ${ }^{8}$

Penggunaan media dalam pembelajaran mampu menghadirkan suatu benda atau peristiwa yang tidak bisa disajikan dalam kelas dengan memvisualisasikannya, selain itu, media juga dapat meningkatkan ketertarikan siswa dalam mendapatkan materi yang diberikan oleh guru. ${ }^{9}$

Media pembelajaran mempunyai beberapa manfaat antara lain: Menjelaskan konsep-konsep yang abstrak dengan detail. (2) Membangkitkan motivasi siswa sehingga siswa tidak bosan dalam belajar. (3) Dapat mengasah semua indra siswa. (4) Mendekatkan teori dengan realita yang sulit didapatkan siswa. (5) Meningkatkan interaksi dan pengenalan secara langsung antara siswa dengan lingkungannya. (6) Meningkatkan keseragaman siswa dalam menangkap materi yang disampaikan. (7) Memberikan materi belajar secara mudah dan dapat diulang-ulang kapanpun. ${ }^{10}$

${ }^{7}$ Sahrani dan Rahnang, "Pembelajaran Muhadatsah Melalui Metode Drama Pada Program Praktikum Jurusan PBA IAIN Pontianak," Ihya Al-Arabiyah: Jurnal Pendidikan Bahasa Dan Sastra Arab 5, no. 1 (2019): 10-32, http://jurnal.uinsu.ac.id/index.php/ihya/article/view/4417.

${ }^{8}$ Amirah Mustarin, Rahmat Arifyansah, dan Muhammad Rais, "Penerapan Media Pembelajaran Adobe Flash CS6 Dalam Meningkatkan Hasil Belajar Siswa Kelas X Atph Pada Mata Pelajaran Alat Dan Mesin Pertanian Di SMKN 4 Jeneponto," Jurnal Pendidikan Teknologi Pertanian 5, no. 1 (2019): 1-8, https://doi.org/10.26858/jptp.v5i1.8189.

${ }^{9}$ Hidayatul Maulidta dan Wahyu Sukartiningsih, "Pengembangan Media Pembelajaran Interaktif Berbasis Adobe Flash Untuk Pembelajaran Menulis Teks Eksposisi Siswa Kelas III SD," Jurnal Penelitian Pendidikan Guru Sekolah Dasar 06 (2018): 681, https://jurnalmahasiswa.unesa.ac.id/index.php/jurnal-penelitian-pgsd/article/view/23703.

${ }^{10}$ Ali Muhson, "Pengembangan Media Pembelajaran Berbasis Teknologi Informasi," Jurnal Pendidikan Akuntansi Indonesia 8, no. 2 (2010), https://doi.org/10.21831/jpai.v8i2.949. 
Produk media pembelajaran yang dihasilkan berupa media pembelajaran berbasis Flash MX. Pengoperasian media berbasis Flash MX ini tidak memerlukan kemampuan khusus, namun hanya bisa dijalankan pada komputer sesuai pada petunjuk penggunaan.

Media pembelajaran berbasis Flash $M X$ memuat 3 materi yang setiap materi terdiri dari teks muhadatsah, mufrodat, dan latihan. Selain itu pada media dilengkapi dengan daftar menu, petunjuk penggunaan, tujuan, standar kompetensi dan kompetensi dasar, gambar dan suara untuk mempermudah dan memperjelas pemahaman siswa. Latihan pada setiap materi berupa pilihan ganda yang terdiri dari 9 soal.

\section{Hasil dan Diskusi}

Dalam model ADDIE terdapat 5 tahapan yaitu Analysis, Design, Development, Implementation, dan Evaluation.

\section{Analysis}

Dalam analisis ini, terdapat beberapa tahap yaitu:

a. Analisis masalah. berdasarkan observasi dan wawancara, siswa kelas 10 di Madrasah Aliyah Al-I'dadiyyah ditemukan beberapa masalah yaitu Belajar dilakukan dengan cara tradisional, perlu untuk mengembangkan model pendidikan yang lebih menarik, Ada fasilitas sekolah seperti monitor LCD yang jarang digunakan untuk belajar, siswa kurang antusias dan kurang tertarik tertarik dalam pembelajaran, maka perlu dikembangkan media yang atraktif dan interaktif yang memiliki penampilan menarik sehingga siswa memiliki motivasi dan minat belajar.

b. Analisis materi. Mengumpulkan materi dari buku pegangan siswa dan mengumpulkan berbagai macam gambar dan gift.

c. Analisis karakteristik siswa. Dalam pengamatan di lapangan, siswa banyak yang merasa jenuh dan bosan. selain itu, banyak yang kurang menguasai materi. Setelah diberikan media pembelajaran berbasis Flash MX, diketahui dari data angket respons peserta didik, siswa lebih tertarik pada media dan lebih menguasai pengoperasian media dalam materi yang diajarkan.

d. Analisis kebutuhan siswa. Berdasarkan hasil pengamatan peneliti diketahui bahwa peserta didik lebih menguasai materi dan memahami apa yang diajarkan karena di dalam media pembelajaran tersebut materi yang dijelaskan lebih mudah dipahami dan lebih banyak gambar yang dapat membantu siswa untuk mengetahui arti dari setiap kalimat, khususnya pada pembelajaran muhadatsah.

\section{Design}

Peneliti mendesain media pembelajaran menggunakan Microsoft PowerPoint dengan memasukkan berbagai gambar dan gift sesuai materi 
yang sudah didapat oleh peneliti. Selain gambar dan gift, peneliti juga menggunakan berbagai fitur yang tersedia pada Microsoft PowerPoint. Setelah selesai mendesain dan mengatur semuanya, media kemudian diflash-kan ke dalam aplikasi Flash MX.

\section{Development}

Pada tahap pengembangan, media pembelajaran yang telah siap maka divalidasikan kepada ahli materi yaitu dosen bahasa Arab dan guru muhadatsah dan ahli media.

\section{Implementation}

Penerapan media dilakukan pada peserta didik kelas 10 dengan jumlah 22 siswa dengan diberikan pre-test dan post-test, setelah diberikan media pembelajaran, siswa diminta untuk mengisi angket respons peserta didik.

\section{Evaluation}

Evaluasi dilakukan untuk mengetahui media pembelajaran berbasis flash MX efektif atau tidak efektif. Evaluasi diperoleh dari hasil respons peserta didik setelah mempelajari materi pada muhadatsah dengan menggunakan media berbasis flash $M X$.

\section{a) Analisis Data}

Uji Kevalidan dan data respons peserta didik. Uji kevalidan dilakukan kepada ahli materi dan ahli media dengan kategori sebagai berikut $^{11}$ :

\begin{tabular}{|c|c|}
\hline Kriteria & Skor \\
\hline Sangat Valid & 5 \\
\hline Valid & 4 \\
\hline Cukup & 3 \\
\hline Tidak Valid & 2 \\
\hline Sangat Tidak Valid & 1 \\
\hline
\end{tabular}

Ahli materi yaitu dosen bahasa Arab yang mendapat nilai 4,1\% dengan kategori sangat valid. Kemudian validasi kepada ahli materi yaitu guru muhadatsah yang mendapat nilai 4,6\% dengan kategori sangat valid dan divalidasikan kepada ahli media yang mendapatkan nilai 3,7\% dengan kategori valid.

\footnotetext{
${ }^{11}$ Sugiyono, Metode Penelitian Kuantitatif, Kualitatif dan $R \& D$ (Bandung: Alfabeta, 2015), h. 135.
} 
Bukti kevalidan dari ahli materi dan ahli media tersebut terbukti bahwa media layak untuk digunakan dalam pembelajaran. Sedangkan analisis respons peserta didik mendapatkan nilai $87 \%$ dengan kategori sangat baik dengan begitu, media pembelajaran berbasis Flash MX layak untuk digunakan pada pembelajaran muhadatsah.

\section{b) Uji Keefektifan}

Pada uji keefektifan ini dilakukan menggunakan pre-test dan posttest. Untuk mengetahui media yang digunakan itu efektif atau tidak bagi peserta didik pada pelajaran percakapan untuk siswa kelas sepuluh. Berdasarkan hasil peneliti menggunakan Uji Normalitas, Uji Homogenitas dan Simple Paired t Test (Uji t Dua Sampel Berpasangan)

Uji Normalitas dengan ketentuan jika nilai Signifikansi $>0,05$, maka nilai residual berdistribusi normal dan jika nilai Signifikansi $<0,05$ maka nilai residual tidak berdistribusi normal.

\begin{tabular}{|l|l|r|}
\hline \multicolumn{2}{|c|}{ Table One-Sample Kolmogorov-Smirnov Test } \\
\hline \multicolumn{2}{|c|}{} & Unstandardized Residual \\
\hline $\mathrm{N}$ & Mean & 22 \\
\cline { 2 - 3 } $\begin{array}{l}\text { Normal } \\
\text { Parameters }\end{array}$ & Std. Deviation &, 0000000 \\
\hline \multirow{2}{*}{$\begin{array}{l}\text { Most Extreme } \\
\text { Differences }\end{array}$} & Absolute & 6,47401834 \\
\cline { 2 - 3 } & Positive &, 176 \\
\cline { 2 - 3 } & Negative &,- 176 \\
\hline Test Statistic &, 176 \\
\hline \multicolumn{2}{|l|}{ Asymp. Sig. (2-tailed) } &, $075^{\mathrm{c}}$ \\
\hline
\end{tabular}

Berdasarkan hasil Uji Normalitas diketahui nilai Signifikansi 0,075> 0,005 maka disimpulkan bahwa nilai residual berdistribusi normal.

Uji homogenitas dengan ketentuan jika nilai Signifikansi $>0,05$ maka distribusi data adalah homogen dan jika nilai signifikansi $<0,005$ maka berdistribusi tidak homogen.

\begin{tabular}{|r|r|r|rr|}
\hline \multicolumn{4}{|c|}{ Table Test of Homogeneity of Variances } \\
\hline \multicolumn{4}{|c|}{ HASIL BELAJAR SISWA } \\
\hline $\begin{array}{c}\text { Levene } \\
\text { Statistic }\end{array}$ & df1 & df2 & Sig. & \\
\hline 3,160 & 1 & 42 & &, 083 \\
\hline
\end{tabular}

Berdasarkan hasil uji homogenitas di sini terlihat Sig 0,083 sebagaimana hasil dari keputusan homogenitas nilai signifikansi lebih besar dari 0,05 maka data tersebut homogen. 


\section{c) Uji Simpel Paired t Test (Uji t Dua Sampel Berpasangan)}

Berdasarkan hasil Uji Normalitas di atas sudah diketahui bahwa bernilai berdistribusi normal dan Uji Homogenitas bernilai berdistribusi homogen, maka selanjutnya adalah Uji Simple Paired t Test. Pada Uji Paired $t$ Test ini data yang digunakan adalah Pre Test dan Post Test. Berikut ini adalah hasil dari Uji Simpel Paired t Test :

\begin{tabular}{|c|c|c|c|c|}
\hline \multicolumn{5}{|c|}{ Table 4.12 Paired Samples Test } \\
\hline & \multicolumn{4}{|c|}{ Paired Differences } \\
\hline & & $\begin{array}{c}\text { Std. } \\
\text { Deviatio }\end{array}$ & Std. Error & $\begin{array}{l}\text { 95\% Confidence } \\
\text { Interval of the } \\
\text { Difference }\end{array}$ \\
\hline & Mean & $\mathrm{n}$ & Mean & Lower \\
\hline $\begin{array}{c}\text { Pair 1 } \\
\text { Pre Test } \\
\text { - Post } \\
\text { Test }\end{array}$ & $38, \overline{182}$ & 10,970 & 2,339 & $-43,046$ \\
\hline
\end{tabular}

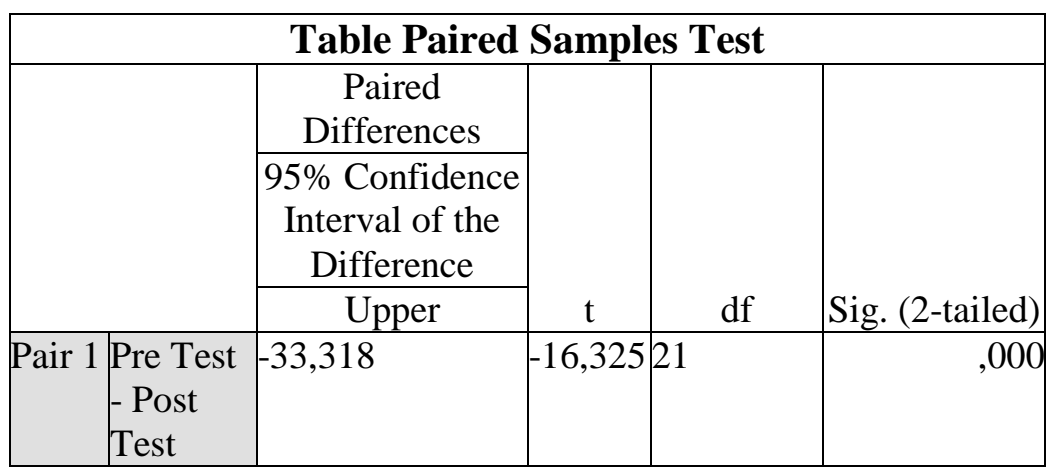

Berdasarkan Nilai Probabilitas:

a. Ketentuan: jika Probabilitas $<0,05$ maka $H_{o}$ ditolak maka $H_{a}$ diterima, dan jika Probabilitas $>0,05$, maka $H_{o}$ diterima maka $H_{a}$ ditolak.

b. Keputusan :Bahwa keefektifan media pembelajaran berbasis Flash $M X$ dapat disimpulkan bahwa hasil uji t Dua Sampel Berpasangan (Paired Sample $t$ Test) adalah 0,000 < 0,05 (0,000 kurang dari 0,05) maka $H_{a}$ diterima maka $H_{o}$ ditolak jadi artinya Pengembangan media berbasis Flash MX Efektif digunakan dalam pembelajaran muhadatsah kelas sepuluh.

Berdasarkan Uji Normalitas, Uji homogenitas dan Uji Simple Paired t Test bahwa hasil dari data Pre Test dan Post Test diketahui bahwa pengembangan media pembelajaran berbasis Flash MX efektif digunakan dalam pembelajaran muhadatsah untuk kelas sepuluh. 


\section{E. Kesimpulan}

Prosedur pengembangan media pembelajaran berbasis flash dilakukan dengan menganalisis masalah yang ada di kelas sepuluh terlebih dahulu. Kemudian peneliti mengumpulkan materi untuk media yang akan dikembangkan. Setelah media selesai, media divalidasikan kepada ahli materi dan ahli media, kemudian media diujicobakan kepada peserta didik dengan jumlah 22 peserta didik. Sebelum siswa diberikan media pembelajaran, siswa diminta untuk mengerjakan pre-test terlebih dahulu, baru kemudian siswa diberikan media. Siswa membaca teks percakapan atau muhadatsah kemudian mendengarkan dan mengoreksi cara baca peserta didik sesuai dengan suara pada media, kemudian peserta didik mengartikan dengan mufrodat yang disediakan kemudian menjawab soal yang ada di media. Setelah diberikan media, siswa diminta untuk mengisi angket respons peserta didik dan mengerjakan pre-test. Pada tahap Validasi dan Uji coba produk, dapat disimpulkan bahwa media pembelajaran berbasis Flash Mx sangat baik dan layak untuk digunakan dalam pembelajaran muhadatsah pada materi kelas X MA Al-I'dadiyyah. 


\section{Daftar Pustaka}

Al-Samman, Muhammad Ali. Orientasi dalam Pengajaran Bahasa Arab. Mesir: Dar Al-Maarif, 1983.

El-Sayed, Mahmoud Ahmed. Dalam Cara Mengajar Bahasa Arab. Datsak: Preserved Publishing, 1997.

Hakim, Muhammad Luqman, Asrowi Asrowi, dan Akhyar Akhyar. "Pengembangan Multimedia Interaktif Mata Pelajaran Bahasa Arab Materi Profesi Bagi Siswa Kelas VIII SMP IT Al-Huda Wonogiri." JTP - Jurnal Teknologi Pendidikan 20, no. 3 (2018): 249. http://journal.unj.ac.id/unj/index.php/jtp/article/view/9537.

Maulidta, Hidayatul, dan Wahyu Sukartiningsih. “Pengembangan Media

Pembelajaran Interaktif Berbasis Adobe Flash Untuk Pembelajaran Menulis Teks Eksposisi Siswa Kelas III SD." Jurnal Penelitian Pendidikan Guru Sekolah Dasar 06 (2018): 681.

https://jurnalmahasiswa.unesa.ac.id/index.php/jurnal-penelitianpgsd/article/view/23703.

Muhson, Ali. "Pengembangan Media Pembelajaran Berbasis Teknologi Informasi." Jurnal Pendidikan Akuntansi Indonesia 8, no. 2 (2010). https://doi.org/10.21831/jpai.v8i2.949.

Mustarin, Amirah, Rahmat Arifyansah, dan Muhammad Rais. "Penerapan Media Pembelajaran Adobe Flash CS6 Dalam Meningkatkan Hasil Belajar Siswa Kelas X Atph Pada Mata Pelajaran Alat Dan Mesin Pertanian Di SMKN 4 Jeneponto." Jurnal Pendidikan Teknologi Pertanian 5, no. 1 (2019): 1-8. https://doi.org/10.26858/jptp.v5i1.8189.

Sahrani, dan Rahnang. "Pembelajaran Muhadatsah Melalui Metode Drama Pada Program Praktikum Jurusan PBA IAIN Pontianak." Ihya Al-Arabiyah: Jurnal Pendidikan Bahasa Dan Sastra Arab 5, no. 1 (2019): 10-32. http://jurnal.uinsu.ac.id/index.php/ihya/article/view/4417.

Santoso, Singgih. Menguasai Statistik dengan SPSS 25. Jakarta: PT Elex Media Komputindo, 2018.

Shodiq, Muhammad Jafar. "Pembelajaran Bahasa Arab Aktif-Inovatif Berbasis Multiple Intelligences." Al Mahāra: Jurnal Pendidikan Bahasa Arab 4, no. 1 (2018): 125. https://doi.org/10.14421/almahara.2018-041-07.

Sugiyono. Metode Penelitian Kuantitatif, Kualitatif dan R \& D. Bandung: Alfabeta, 2015.

Suryani, Nunuk, Achmad Setiawan, dan Aditin Putria. Media Pembelajaran Inovatif dan Pengembangannya. Bandung: PT. Remaja Rosdakarya, 2018. 
100 | Farida Nur Jannah, M. Dzikrul Hakim Al Ghozali 